\title{
Trade, Violence and Diplomacy on the Coast of Ikorodu: The Resistance of Balogun Mabadeje Jaiyesimi
}

\author{
Adebowale Adeyemi-Suenu \\ Lagos State University, Nigeria \\ ololadeololade70@gmail.com
}

\begin{abstract}
From the 1850s, British influence in Lagos and coastal Nigeria expanded, leading to the annexation of Lagos in December 1861 and the establishment of Lagos Colony in 1862. This period also witnessed the British quest for the control of coastal and inland trade routes. Ikorodu's location north of Lagos and on the lagoon, and its control of trade from the coast to Sagamu, the main city of Remo, involved the town in larger struggles between the ljebu kingdom and the Egba settlers at Abeokuta, and in the expansionist plans for Lagos under Governor Henry Stanhope Freeman (1862-4) and his successor, Captain John Hawley Glover (1864-6).

This article explores how lkorodu successfully manoeuvred between these different interests under the leadership of Balogun Mabadeje Jaiyesimi to defeat its external aggressors and to increase its independence. It not only addresses the dearth of published work on Ikorodu but also provides a response to Earl Phillips' discussion of the unsuccessful 1864-5 Egba attack on Ikorodu. Unlike Philips, who suggests that the Egba defeat was primarily engineered by John Glover, this article emphasises the importance of Balogun Jaiyesimi's strategic and negotiating skills, which led to the formation of a local coalition between lkorodu and its neighbouring towns, especially Igbogbo, to ensure Ikorodu's military victory.
\end{abstract}




\section{Introduction: The rise of Ikorodu}

The nineteenth century history of Yorubaland was predominantly the history of war, violence, diplomacy and intrigues. In the interior, the collapse of the Oyo Empire led to protracted civil war, from which emerged the new warrior cities of Ijaye, Ibadan, and Abeokuta. Along the coast, the British fight against the slave trade, coupled with the desire to expand control over legitimate trade, led to an increasing British presence. Ikorodu's role in these larger conflicts was determined by its favourable position at the cross-roads of several trade routes and political centres of power. Ikorodu was originally a political and trading outpost of the Ijebu kingdom, which participated in the politics the interior first as an ally and later as an opponent of the warrior city of Ibadan, founded in 1829 mainly by refugees from the destroyed Oyo Empire. In the first half of the nineteenth century, Ikorodu's geographical proximity to Lagos meant that a growing segment of the trade between Lagos and Ibadan - and especially the lucrative trade in guns and gunpowder that enabled Ibadan's rise to regional hegemony - passed through Ikorodu and later through the Ijebu province of Remo. ${ }^{1}$ Ikorodu also ensured the safety of trade from Ijebu-Ode through Itoikin to Lagos.

As Ikorodu's success in leveraging its position has allowed it to assert independence both from the Ijebu capital Ijebu-Ode and from Ofin, ${ }^{2}$ the leading town in Remo (now in the Remo capital Sagamu), different versions of its history have been highlighted at different times. As most Yoruba speakers understand a town's origin or foundation as indicating belonging, claims to different historical origins have been made largely for political purposes, and Ikorodu leaders have variously highlighted its links to Ofin, Sagamu and Remo, to Ijebu-Ode, and even to Benin. Thus the fact there is no firm agreement today on the early history of Ikorodu is partly the result of the town's rise to significance.

Overall, however, there seems to be a bias towards confirming the town's origin from Remo. There is little disagreement that the town's first ruler, or Oloja of Ikorodu, was Oga, a great hunter and a warrior who went on a hunting expedition from Ofin, Sagamu to the lagoon beach of Ipakodo where Sekunmade, his elder brother and also a prince, had already settled. ${ }^{3}$ Today,

1. A. Talabi, Trade Routes in Remoland in the 18th and 19th century (Ijebu-Ode: Bathom Press, 1989), 7.

2. I.A. Ademiluyi and A.S. Okude, 'A Survey of Inter-Group Relations in Ijebuland in the $19^{\text {th }}$ century', in O.O. Olubomehin, ed., The Ijebu of Western Nigeria: A Historical and Socio-cultural study (Ibadan: O.O.U. College Press, 2001), 11.

3. A. Matthew, 'Ikorodu: Yesterday, Today, and Tomorrow', published speech at the 1st Ikorodu Oga day celebration (Ikorodu, 1992), 18. 
there are different quarters of the traditional town that point to the origin of their inhabitants from Remo, including Itun Layeode, linked to Ode-Remo; Itun Soku, linked to Isokun (a location west of Sagamu); and Itun Elepe, linked to Epe (now in Sagamu). In addition, other migrants from Idowa near IjebuOde came with the cult of Agemo and settled in Ikorodu at the present Itumoja. Equally, some Edo (Benin) migrants came to Ikorodu. Their descendants remain the holders of the Olisa chieftaincy title in Ikorodu today. Interestingly, these fundamental historical differences that are often the cause of crises and division in other Yoruba settlements have not affected Ikorodu significantly. Today, Ikorodu is divided into four segments; Isele, Ijomu, Aga and Itumoja. Their different social and cultural activities reflect their different origins.

In the 1850s, the Church Missionary Society (CMS) minister David Hinderer noted the strength of the support for Ijebu-Ode in Ikorodu. ${ }^{4}$ This support reflected the fact that Ikorodu's loyalty to Ijebu-Ode had enabled it to expand its local influence beyond the original settlement. To tax and control trade along the land route from the lagoon market of Ejinrin to Lagos, Ikorodu was allowed to station its representatives in Itamaga and Ota Ona, two locations east of Ikorodu. The town also had an outpost at Agbala, west of Ikorodu, where its representatives would control trade from Lagos towards Ibadan. ${ }^{5}$

While its original settlement is located at a distance from the coast, Ikorodu also established its influence over the smaller coastal settlements of Ipakodo and Ebute-Iga, despite the fact that these settlements were older than Ikorodu. As the age of a settlement is often an indicator of its seniority, this achievement indicates both the town's wealth and the success of its leaders in maintaining their control of local income from trade. ${ }^{6}$

This success was owed, to a large degree, to Balogun Jaiyesimi of Ikorodu. In almost all Yoruba towns, the Balogun is the leader of the town's warriors, and this was the case in Ikorodu too. Given the frequent wars and ongoing raids for domestic slavery at the time, Ikorodu's control of local trade was not just in the hands of market leaders but also of soldiers. It was therefore Balogun Jaiyesimi's ability to control and manage the soldiers of his town that benefited Ikorodu and, by extension, also the other settlements in Ikorodu's vicinity that shared in the wealth created by the efficient control of local trade, coastal trade and different trade routes.

4. B. Awosika, 'Inter-Group Relations in Yorubaland in the 19th and early 20th centuries in Ijebu and Remo Lands', (M.A. diss., Lagos State University, 2004), 17.

5. O. Rowland, 'The Prelude to Agbala War in the 19th Century', Oriwu Sun, [full date missing] 2016, 7.

6. A. Adeyemi-Suenu, 'Ikorodu and Her Neighbours: Politics of Development and Integration in Yorubaland in the 19th century', unpublished paper delivered at Ikorodu Youth Forum, Ikorodu Local Government (2013): 3-4. 
By the mid-nineteenth century, Ikorodu had several major markets. ${ }^{7}$ These markets were, however, periodic markets where trade took place in intervals of nine or seven days, and as part of a network of markets that opened on different days. The most famous of the three markets is Iworo and Ajina market in the old centre of the town. Another market is Obun Ale, which is close to Jaiyesimi compound. Another market, Oja Ebute, is on the coast of Ipakodo by the lagoon. Like Iworo and Ajina, all these markets have presently assumed the status of daily markets without abandoning their traditional periodic variables and essence.

Two of these markets are illustrative of the principle that traditionally, markets are understood as governed by spiritual forces, and they are often set up in close proximity to places of ritual political importance, such as rulers' palaces, the shrines of local deities, or the meeting houses (conclaves) of secret societies. The Iworo and Ajina market, where slaves and products from upcountry were exchanged with traders before being taken to the port at EbuteIga, is held at the old palace of the Ayangburen, the ruler of Ikorodu. Today the palace and the market places remain the central location for the town's major traditional festivals, such as the ancestral Oro association, the major groves of the town's deities, and the conclaves of the major and most important traditional cults such as the Osugbo, which advises the ruler. ${ }^{8}$

The emergence of Obu Ale illustrates the importance of Balogun Jaiyesimi for Ikorodu during this period. In Yoruba towns, the Balogun is typically the leader of the town's warriors, and this was the case in Ikorodu too. The emergence of a market by Jaiyesimi's compound reflects the fact that the town's growing wealth was closely linked to the military, and it confirms his importance for Ikorodu even before the beginning of military confrontation.

\section{Ikorodu at the crossroads of regional politics, 1860-64}

As set out above, Ikorodu's wealth and importance were closely linked to its location at the south-western boundary of the Ijebu kingdom, and the growth of Lagos and Ibadan, which was an ally of Ijebu-Ode. However, by 1860, this would change. By this time, rivalry between Ibadan and Ijaiye, a rival warrior city, increasingly tilted in favour of Ibadan. Ibadan's growing hegemony in the region worried the paramount ruler of Ijebu kingdom, the Awujale of IjebuOde. Ijebu had long been allied to Ibadan, as the collaboration of the two pol-

7. S. Arogunre, 'Contributions of Iworo market to the origin and development of Ikorodu', (B.A. diss., Lagos State University, 2015), 28.

8. A. Sakiru, 'Ejina and Iworo Market: The Siamese Twins', Oriwu Sun, 22 January 2014, 3. 


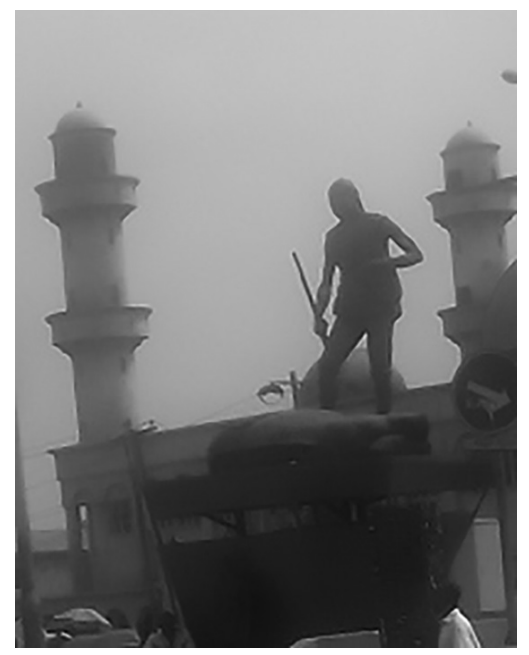

Figure 1: The Statue of Oga, the Founder of Ikorodu's monarchical order. Source: Author's photograph

ities ensured Ibadan's supply with weapons and contributed to Ijebu's wealth. However, fearing that its erstwhile partner would soon pose a threat, IjebuOde now formed an alliance with its former enemy Abeokuta. Together, Ijebu and Egba leaders agreed, they could support Ijaiye by blocking trade to Ibadan and thus keep its military influence in check.

This decision, made in the Ijebu capital, did not meet with universal support across the Ijebu kingdom. Like Ikorodu, several Remo towns were bitterly opposed to the decision. Ikorodu and the larger Remo market towns along the main trade route, such as Makun, Iperu, Ode Remo, and Ipara, had benefited most from the trade between Lagos and Ibadan, and simply ignored the instructions from the capital. When Ijebu-Ode sent 40 messengers to Makun to reason with the rebels, they were killed. ${ }^{9}$ By keeping the trade routes open between Lagos and Ibadan, Ikorodu and its Remo allies made an important contribution to Ibadan's victory over Ijaye and its Egba and Ijebu allies in early 1862. ${ }^{10}$ To avenge the murder of his messengers and Ijebu's military defeat in Ijaye, the Awujale subsequently invited the Egba armies to punish the Remo 'rebels'. Ibadan's support came too late, and in May or June 1862, Makun was destroyed. At first the Remo 'rebel' towns continued to support Ibadan, but by

9. O. O. Ayantuga, 'Ijebu and its Neighbours, 1851-1914', (PhD diss., University of London, 1965), 128-9.

10. I. Nolte, Obafemi Awolowo and the Making of Remo: The Local Politics of a Nigerian Nationalist (Edinburgh: Edinburgh University Press, 2009), 80. 
1864 many of them had been destroyed by the Egba-Ijebu alliance and accepted defeat. ${ }^{11}$

However, Ikorodu was not included in the defeat of its allies because the alliances involving Lagos had also shifted: Ikorodu had been declared a protectorate under Governor Freeman (1862-4) in 1862. Both Freeman and his successor Glover (1864-6) were determined to open the trade route to the hinterland again to raise income from customs duties, and their interest in Ikorodu protected the town from any possible Egba attacks (even though protection was later withdrawn and no attempt was made to establish formal British governance until the 1890s). In fact, Lagos's interest in Ikorodu also indirectly encouraged Ikorodu's raids on the Egba war-camps on Remo territory. This reflected a change in Lagos attitudes towards Abeokuta, which had hitherto been a close ally.

The new politics from Lagos did not entail a change of attitudes towards Ijebu-Ode, whose close control of trade had irritated the British for some time. Both Freeman and Glover thought that the decision to close the trade routes was motivated by the greed of Abeokuta and Ijebu-Ode rather than their political concern. Thus, when Glover mobilised a contingent of the Lagos military and the Hausa police to defend Ikorodu against a feared attack in 1863, he is likely to have pursued the long-term aim of excising Ikorodu from Ijebu. ${ }^{12}$ Under the circumstances, this suited Ikorodu leaders very well.

However, in August 1864, Glover contacted the leaders of the Egba army then still based at Makun, to invite them to a meeting, where the establishment of diplomatic relations and of a formal boundary between Lagos and Abeokuta were discussed. In return for these concessions from Abeokuta, Glover agreed that if Abeokuta could defeat Ikorodu within 10 days, Lagos would not intervene. Indeed, to demonstrate his faithfulness, Glover agreed to set up a naval blockade around Ikorodu, depriving it of trade and the possibility of escape by water in the case of an attack. Delighted to have an opportunity to strike back at their Ikorodu enemies, the Egba warlords agreed to sign the treaty after they had taken Ikorodu. ${ }^{13}$ With the blockade in place, the Egba then laid siege to Ikorodu.

Earl Philips suggests that this treaty was meant as a trap, and that Glover's sole aim in initiating it was in luring the Egba armies to Ikorodu in order to weaken and defeat them. He suggests that Glover knew well that the formidable Ikorodu army could not be defeated in ten days by the Egba forces. Indeed,

11. Ibid., 81 .

12. E. Phillips, 'The Egba at Ikorodu, 1865: Perfidious Lagos?', African Historical Studies, 3:1 (1970), 28-30.

13. Ibid., 29-31. 
he points out that the naval blockade did not impair Ikorodu's ability to defend herself, and that Glover later encouraged Ibadan to defend Ikorodu and even provided Ikorodu with gunpowder for its defence. ${ }^{14}$

However, it is also possible that Glover's invitation to the Egba was a gamble, in which he hoped to gain either way. Certainly, if the Egba failed to take Ikorodu, Glover might defeat them, either directly or with the help Ibadan, and thus weaken the Egba hold on trade with the hinterland. But if the Egba were able to take Ikorodu, this would also be a major blow to Ijebu control of the trade to Ibadan. Meanwhile, the agreed Egba concessions to Lagos would allow for the expansion of trade with the hinterland. Moreover, if the Egba, as experience in Remo suggested, refused to leave Ikorodu after the defeat, this would further weaken the Egba-Ijebu alliance, and allow Lagos to mobilise supporters of its position in Ijebu against the Egba.

Given Glover's scepticism of both Abeokuta and Ijebu-Ode, and his political flexibility, a win-win gamble seems a more natural explanation than an elaborate anti-Egba plan. In this case, the outcome of the Egba siege of Ikorodu cannot be seen as the result of British machinations, or even as predetermined by them. In that case, we must also explore the conflict through a look at relations of power and the agency of African leaders and followers on the ground.

It is, however, important to note that in Ikorodu, it was believed that there existed an agreement between Ibadan and Balogun Jaiyesimi, which was based on Lagos's promise to support Ikorodu and Ikorodu's promise, in return, to ensure and support the access of Ibadan to the coast for the purpose of securing war ammunitions. Whether this agreement was fully honoured by Glover or not, the Ikorodu chiefs were determined to honour it, and their belief in the benefits of the agreement created a certain degree of confidence in Ikorodu that may have contributed to their diplomatic and military success.

\section{Balogun Mabadeje Jaiyesimi and the defence of Ikorodu, 1864-5}

Once established, the Egba siege - locally known as Agbala War - did not only reflect the ambitions and concerns of Lagos, Ijebu-Ode, and Abeokuta, but also the interests of their local allies. ${ }^{15}$ The desire by Ijebu-Ode to maintain direct access to the coast near Lagos meant that the Awujale of Ijebu-Ode leaned on the coastal settlements of Agbowa and Imota to re-assert his power over Ikorodu. ${ }^{16}$ In nearby Ofin, the Akarigbo, whose support of Ijebu-Ode

14. Ibid., 31-2.

15. O. Sehindemi, 'The Agbala War in the $19^{\text {th }}$ Century: Celebration of Ikorodu warriors', a speech at the Ikorodu Oga carnival, 2009.

16. These settlements link Ijebu-Ode to Ikorodu. 
during the Remo 'rebellion' had strengthened his own position, also wanted to retain access to Ikorodu. Moreover, the rise of Ikorodu had created resentment among its neighbours. The settlements that predated the establishment of Ikorodu were especially unhappy with Ikorodu's influence over their affairs and in their domain and sought to overcome the continuous domination of Ikorodu was primary in the calculation of the two coastal settlements. ${ }^{17}$

When the Egba marched on Ikorodu, they were supported by Ebute-Iga and Ipakodo, the two coastal towns over which Ikorodu had extended control despite their greater age. In the meantime, the Ijebu armies had moved past Agbowa and Imota to Baiyeku, a historical town located to the south-east of Ikorodu whose leaders remained loyal to the Awujale. While Ebute-Iga and Ipakodo promised to prevent the Ikorodu army from escaping so they could be crushed, Baiyeku marched to Ikorodu from the southeast. Determined to attack Ikorodu, Baiyeku mobilised support from other settlements surrounding Ikorodu, including Langbasa, Imota and Ibeshe. As the growing army passed the settlement of Igbogbo, Balogun Jaiyesimi acted decisively to defend his town.

Balogun Mabadeje Jaiyesimi was born in the first half of the nineteenth century as the heir to three royal families from the Ijebu kigdom. According to legend, he was born as a warrior. When his mother consulted the Ifa oracle during pregnancy to enquire about the baby in her womb, she was told that she should start a trade in ammunitions to ensure the greatness of her child. However, she was warned to be generous in her trade, and to give credit or even free goods if that was asked of her. It is said that she heeded this advice. When her child was born, he was called Jaiyesimi, meaning 'enjoy the world and rest', or 'let the world rest', to foreshadow the greatness predicted by the Ifa oracle.

Balogun Jaiyesimi's father Jolugbo was the son of Oba Afonlade Osan, the Alaye Ode of Ode Remo. ${ }^{18}$ His mother Mabunmi's paternal forebear was Oba Anoko of Ofin, the Akarigbo in Sagamu in Remoland. ${ }^{19}$ On her maternal side she was also descended from an Ajalorun of Ijebu-Ife (near Ijebu-Ode). Jaiyesimi's affluent background notwithstanding, this illustrious, industrious and hardworking individual grew up to be a successful hunter, a great farmer and a formidable warrior that was to live up to the meaning of his name. Reflecting his skills, Jaiyesimi was an avowed worshipper of Ogun, the God of iron, warfare and hunting in Yoruba tradition. As Ikorodu's Balogun, Jaiyesimi built a

17. Interview with High Chief Adeleke Atunfagbon, aged 89 years, Ebute Road, Ipakodo, Lagos State.

18. It is not clear which Alaiye Ode this is as there are several Alaiye Ode bearing Afonlade, because it is a branch of the family.

19. This ruler is officially recognised as a past Akarigbo of Ofin (Sagamu). 


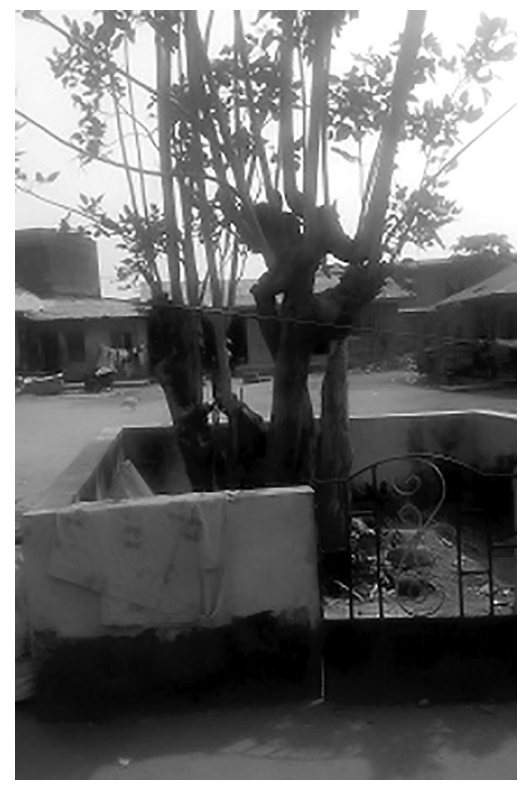

Figure 2: Balogun Jaiyesimi's modernized Ogun shrine in the palace compound. Source: Author's photograph

large compound which still exists in Ikorodu and housed his own family as well as members of the army. The hospitality of the compound is illustrated by the fact that this compound was also the location of the town's first mosque at Oburoke, which was built by him in obedience to the directive by the Ifa oracle. Later the town's first CMS church was also built near the market of Obun Ale.

While Baiyeku marched on Igbogbo, Balogun Jaiyesimi contacted Bashorun Ijaolu Osho-Ojuba of Igbogbo. A descendant of the Ijaolu royal family of Igbogbo, Osho-Ojuba was related to Balogun Jaiyesimi through his mother's side. ${ }^{20}$ However, he was also an experienced warrior who had gained fame through his successes in the Ijebu army. Upon his return from war, he had centralised the Igbogbo settlement, which was previously dispersed and segmented, and introduced and encouraged the celebration of typically Ijebu festivals such as Agemo. In the spirit of the times, he also built a formidable army to defend the newly centralised town.

Realising that Igbogbo had an interest in maintaining control of the community's boundary at Oreta and Oreyo, which were also claimed by Baiyeku,

20. Interview with Pa Adesanya Ogbe, aged 95 years at Town Hall, Ikorodu, Lagos, 18 September 2016. 


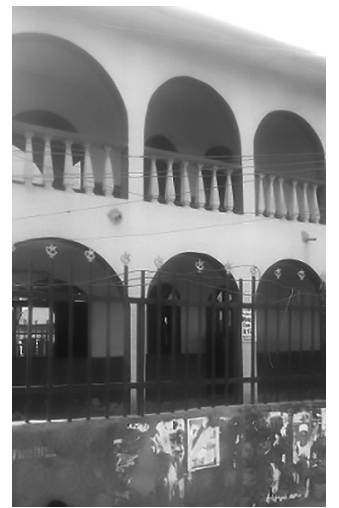

Figure 3: The mosque built by Balogun Jaiyesimi. Source: Author's photograph

Balogun Jaiyesimi convinced Bashorun Ijaolu Osho-Ojuba to join a coalition with him against the Egba and Ijebu forces. This was the famous Ikorodu-Igbogbo alliance. Leading his forces against Baiyeku and its allies, Bashorun Osho-Ojuba secured Ikorodu's south-east flank. This enabled Balogun Jaiyesimi to hold out against Ebute-Iga and Ipakodo, and their Egba allies for several weeks. $^{21}$

As Governor Glover only decided to support Ikorodu after the town had withstood several months of siege, it is certainly possible that he hoped at first that the Egba would win and that Lagos would subsequently enjoy the benefits of the already negotiated treaty with them. However, as the strategic diplomacy, the military successes, and the faithful support of Lagos interests by Ikoro$\mathrm{du}$ and Igbogbo showed that the town was able to withstand the aggression, Glover eventually sided with Ikorodu formally. It was at this stage that he assisted the town through the delivery of gunpowder, and by calling on Ibadan to defeat the Egba.

When Ibadan had not responded by March 1865, Glover went to Ikorodu for a short visit, presumably to alert the town of his plans to offer military support to Ikorodu himself. A few days later, a British expedition including 250 West Indian troops attacked the Egba, who were defeated decisively and withdrew. ${ }^{22}$ It should be noted that at this time, one of Balogun Jaiyesimi's warrors, named Otambala, was allowed to give strategic military support to the British troops because of his knowledge of the local geographical and social factors. Otambala later became a Balogun himself.

21. Interview with Chief Gafaru Mashe, the Head of Ija-Olu Osho-Ojuba family, Igbogbo, aged 91 years at 94, Igbogbo road, Ikorodu, Lagos.

22. Phillips, 'The Egba at Ikorodu', 33-4. 


\section{Conclusion and outlook}

The technological superiority of the colonial conquerors tempts the historian to understand history as the result of European activity and to disregard local agency. Coupled with the relatively easy availability of colonial documentation, which makes access to the past from the point of view of colonial officials easy, this can lead to historical interpretations that over-emphasise or even over-interpret colonial agency. As this article has illustrated, the defeat of the Egba at Ikorodu was at least as much the result of Balogun Jaiyesimi's diplomatic and military skills and Balogun Ijaolu Osho-Ojuba's military ingenuity as of the erratic policies of Governor Glover.

It is more frequently recognised that the same principle applies to the aftermath of great events, which often have important - and not always intended - local consequences. Thus the Lagos intervention in Ikorodu is often primarily discussed with regard to the Egba 'Ifole', or expulsion of Europeans, in 1867, which arose at least partly from the growing suspicion of Britain after Glover's betrayal of the Egba forces he had invited to Ikorodu. The annexation of Ikorodu by Lagos is also often understood as one of the reasons for Ijebu-Ode's ban on European travellers (including missionaries), and its return to an uncompromising close control of any trade passing through its territory, which eventually led to its military defeat in 1892 .

But what is often forgotten is that even as the 1865 war meant a defeat for both Abeokuta and Ijebu-Ode, it was an important victory for Ikorodu and her allies. It certainly led to a further centralisation of power in the Ikorodu area as both Ikorodu and Igbogbo asserted their authority. Bashorun Ijaolu Osho-Ojuba confronted the intrigues from the neighbouring settlements and won the boundary wars against Oreta and Oreyo. At this point, the leadership and indeed obaship (kingship) of Igbogbo Kingdom naturally fell on his shoulders, and he had a successful reign. He built a separate palace, the ruin of which is still visible today, and served his community as a priest and a native doctor. He subsequently laid down his life as a sacrifice for the growth, spiritual stability and security, sustenance and development of Igbogbo kingdom.

In Ikorodu, Balogun Jaiyesimi confirmed the town's victory by first impressing on the rebellious communities of Ipakodo and Ebute-Iga that he now had the support of Lagos. However, he also began to reconcile the settlements that had been aggrieved by the conflict. This diplomatic master-stroke, the pinnacle of traditional diplomatic ingenuity, ultimately made Balogun Jaiyesi$\mathrm{mi}$ the symbol of unity in that social hemisphere. Jaiyesimi built on his popularity to increase his - and his town's - wealth. By 1892, when Lagos defeated Ijebu-Ode and finally annexed Ikorodu formally, Jaiyesimi was said to have 
four hundred slaves. ${ }^{23}$ Indeed his popularity was so much greater than both that of the Oloja, or ruler, and the traditional governing council (Osugbo) that he was often mistaken as the town's king.

Unfortunately the formal incorporation of Ikorodu into the Protectorate also meant that Balogun Jaiyesimi could no longer hold on to his slaves, and as many of them left him, his wealth declined. However, he was compensated to some degree when in 1894 the colonial government established a Local Government Council for the newly created Ikorodu District. Until 1901, the council was chaired by Balogun Jaiyesimi, with the town's ruler (the Oloja) and two other chiefs as members. Under the British dispensation, Jaiyesimi received a monthly allowance of one hundred pounds - the same amount as the Akarigbo in Remo, ${ }^{24}$ and twice as much as the Oloja of Ikorodu, who received fifty pounds before he died in 1901. His pivotal role meant that two of his children succeeded him as Balogun; Balogun Akintelu Jaiyesimi (19011924) and Balogun Mabadeje Jaiyesimi (1924-1948). Both in his own right and as the progenitor of what was, for many years, the town's most powerful lineage, Balogun Mabadeje Jaiyesimi can be referred to as the founder of modern Ikorodu.

But beyond his personal and family influence in Ikorodu, Balogun Jaiyesimi was also the leading figure behind the achievement of Ikorodu's independence from Ijebu-Ode and Ofin, now in Sagamu. Ikorodu's victory over the Egba without the help of Ijebu-Ode confirmed its independence, and even though the practical annexation of Ikorodu by Lagos did not take place until the 1890s, the close relationship between Ikorodu and Lagos greatly diminished the power of Ijebu-Ode over Ikorodu. This meant that the town could maintain close control of the wealth made by trade and draw on it to continue its expansion. ${ }^{25}$ Ikorodu's unique identity as a cosmopolitan settlement with close links to both Lagos and Ijebu also reflects the fact that it was able to develop freely.

23. Interview with High Chief Adisa Jaiyesimi, aged 83 years, a great-grandson of Balogun Jaiyesimi, Jaiyesimi Compound, Ikorodu on 12 September 2016.

24. Ikorodu Local Government, Manual, (Ikorodu, 2008), 7.

25. While the inclusion of Remo into the Lagos Protectorate in 1898 might have re-established a degree of control by Sagamu over Ikorodu, the British recognised Ikorodu's importance and included Remo into Ikorodu District (created in 1894) and not vice versa. Moreover, the introduction of Indirect Rule from 1914 meant that Remo, which had attempted a similar, but by then more tentative move towards independence from Ijebu-Ode, was re-integrated into the old Ijebu kingdom. 